\title{
Fenland Ague in the Nineteenth Century
}

\author{
ALICE NICHOLLS*
}

Ague was central to the local construct of health and mortality for both the lay and the medically trained nineteenth-century Fenlanders. The disease was endemic in the marshes of Lincolnshire, Norfolk, Suffolk and Cambridgeshire for the greater part of the century, reaching epidemic proportions between 1826 and 1829, and 1857 and 1860. Mortality from ague was minimal and sporadic, but the disease precipitated a chronic state of ill-health and co-morbidity with other infectious and water-borne diseases of the nineteenth century, a state which profoundly affected the social and economic structures of the area.

This paper examines the prevalence of ague, and its effect on mortality and morbidity in the Fens during the nineteenth century. In particular, it focuses on the Fenlanders' perception of ague. Local synonyms for the disease reflect their understanding of the way it was contracted-paludal fever, marsh fever, autumnal fever; and its effects and behaviour-intermittent fever, periodical fever, the quakes. They even reflect the character of the disease, personifying it as a familiar figure and suggesting a degree of intimacy - the Bailiff of the Marshes, Lord John's fever, Old Johnny Axey.

Nineteenth-century authors believed ague to be malaria and often used the terms interchangeably. The high morbidity and low mortality from the disease and the seasonal pattern of primary infection and relapse suggest a benign, tertian malaria, caused by Plasmodium vivax (rather than the more fatal tertian, P. falciparum). Yet, without clinical evidence of plasmodial infection in Fenlanders, the suggestion is still speculative. ${ }^{1}$ Similarly, there is sparse historical evidence for the distribution of Anopheles mosquitoes, the vector for the parasite, in the Fens. ${ }^{2}$ However, local

\footnotetext{
* Alice Nicholls, 39, Forsyth House, Tachbrook Street, London SW1V 2LE.

I would like to thank Professor Roy Porter and Dr Mary Dobson for their invaluable support and guidance.

${ }^{1} \mathbf{M} \mathbf{J}$ Dobson in 'Malaria in England: a geographical and historical perspective' (Parassitologia, 1994, 36: 35-60, p. 55), states that clinical tests carried out in England in the early twentieth century revealed the presence of Plasmodium vivax in the blood of "ague sufferers".
}

\footnotetext{
${ }^{2}$ The distribution of Anopheles mosquitoes is reported in George H F Nuttall, Louis Cobbett and $T$ Strangeways-Pigg, 'Studies in relation to malaria: the geographical distribution of anopheles in relation to the former distribution of ague in England', J. Hyg., January 1901, 1: 4-44. The authors report sightings of Anopheles in various locations in the Fens (pp. 16-18), but at the time the report was written, the two maculopennis species had not been differentiated. Therefore, the distribution of the $P$. vivax vector, atroparvus, is not clearly denoted.
} 


\section{Alice Nicholls}

literature supports the incidence of malaria on the basis of differential symptomatology, ${ }^{3}$ and the nineteenth-century Fens were an ideal environment to harbour the disease.

\section{The Fenland Environment}

The villages and towns of the area were barely above sea-level, completely encompassed by lower-lying fenland. Consequently, the Fens were susceptible to "sea invasion, tidal incursion and freshwater flooding", ${ }_{4}^{4}$ to the extent that when "the Sea floods and the Land floods meet, as they often times doe ... like two powerful enimies joyning in one, they doe over-run the Levell, and drowne it from one end unto the other". . Dr Robert Hamilton, a physician practising in King's Lynn, Norfolk, at the end of the eighteenth century, referred to the "overflowed and uncultivated" area of fenland surrounding the town as "Marshland, or, as it is pronounced by the inhabitants, Mersland". 6 This tract of land was a hostile and isolated place in which to live, liable to the constant threat of flooding, as Hamilton remarked, "not only at the height of spring-tides, but at other times when there is a hard gale of wind at N.W.". The land was largely inaccessible and this inspired many nicknames for the Fenlanders. They were called "camels" because of their tendency to stalk through the shallow floods on stilts, and "yellow-bellies" because they lived like frogs and were reputed to have webbed feet. ${ }^{8}$ Even their houses were built on stilts or piles, above the boggy fenland (see Figure 1).

\footnotetext{
${ }^{3}$ Mary $\mathrm{J}$ Dobson in Contours of death and disease in early modern England (Cambridge University Press, 1997) mentions six factors which differentiate ague/malaria from other acute fevers-alternating hot and cold stages; periodicity of symptoms; enlargement of the spleen; relapse several months after the primary infection; anaemic condition of the patient and its ability to yield to large doses of quinine (pp. $312-15)$. Reference to these factors is made in a number of primary sources written about the Fens: Samuel H Miller and Sydney B J Skertchly, The Fenland, past and present, Wisbech, Leach \& Son, 1878, p. 357 (yielding to quinine); p. 416 (enlargement of the spleen), p. 420 (alternating hot and cold stages); Sixth report of the Medical Officer of the Privy Council with appendix, 1863, London, HMSO, 1864, Appendix 13 (periodicity of symptoms and spring relapse); Charles Murchison, 'Clinical lecture on the causes of intermitting or paroxysmal pyrexia, and on the differential characters of its several varieties', Lancet, 1879, i: 617-19, p. 617 (spring relapse).

${ }^{4}$ A K Astbury, The black fens, Cambridge, Golden Head Press, 1958, p. 4.

${ }^{5}$ A Burrell, $A$ briefe relation discovering plainely the true causes why the great Levell of the
}

Fenns in the severall counties of Norfolk, Suffolk, Cambridge, Huntington, Northampton and Lincolne Shires ... have been drowned and made unfruitfull for many yeares past, London, Constable, 1642, p. 5. In the generation before Burrell, William Camden, who himself suffered from ague, also documented the inundation of Cambridgeshire. In Britannia: or, a chorographical description of the flourishing kingdoms of England, Scotland, and Ireland, and the Islands adjacent, from the earliest antiquity (1806 edition, p. 211), he wrote, "The farther and Northernmost part, which by the frequent overflowing of the rivers is marshy and divided into islands...".

${ }^{6}$ Robert Hamilton, Observations on the marsh remittent fever, more particularly in regard to its appearance and return every autumn, after the inundation from the sea, on the first of January, 1795, and the five succeeding years, at Lynn, and its environs, London, J Mawman, 1801, p. 31. I am very grateful to Dr Peter Cave for drawing my attention to this essential source.

${ }^{7}$ Ibid., p. 30.

${ }^{8} \mathrm{~W}$ E Dring, The Fenland story from prehistoric times to the present day, Cambridge, Cambridgeshire and the Isle of Ely Education Committee, County Library, 1967, p. 33. 


\section{Fenland Ague in the Nineteenth Century}

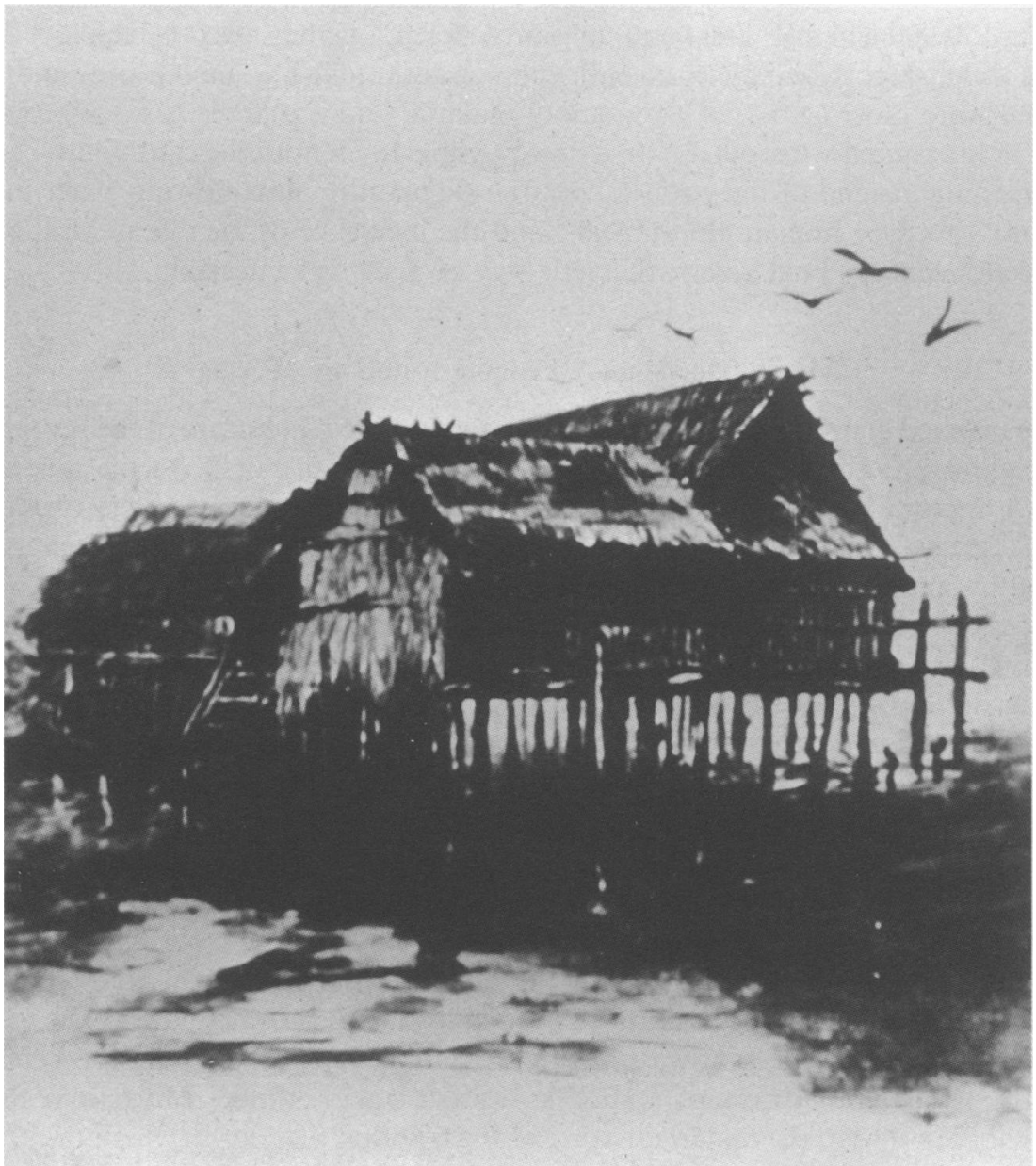

Figure 1: Ancient Fenhouse on piles c. 1790.

(From Cambridgeshire Collection, Cambridge Central Library.)

Although the flourishing nineteenth-century opium trade centred on Fenland towns and cities such as Wisbech and Ely, ${ }^{9}$ the land itself held very little economic reward in its then flooded state. Despite mercantile efforts, by the turn of the nineteenth century only 50,000 acres of Cambridgeshire fenland had been drained,

${ }^{9}$ See V Berridge, 'Fenland opium eating in the nineteenth century', Br. J. Addict., 1977, 72: 275-84; V Berridge, 'Opium in the Fens in nineteenth century England', J. Hist. Med. Allied
Sci., 1979, 34: 293-313; V Berridge and G Edwards, Opium and the people: opiate use in nineteenth-century England, London, Allen Lane, 1981. 


\section{Alice Nicholls}

leaving 150,000 acres of waste and unimproved fen,${ }^{10}$ waterlogged by shallow floods. It was widely recognized by nineteenth-century authors that inhabitants of undrained fenland were most at risk of contracting malaria, "all are liable to its attacks who dwell in low, marshy districts". ${ }^{11}$ It is now possible to identify the causal link between the breeding ground of the parasite vector-stagnant or slow-flowing water in close proximity to their human blood meal-and the incidence of the disease, but for the nineteenth-century Fenlanders, the aetiology of ague was uncertain.

\section{Marsh Miasma-A Fenland Aetiology of Ague}

The infected air of the Fens, described in topographical literature of the seventeenth and eighteenth centuries, may have been a conceptual precursor to the nineteenthcentury miasmatic explanation of disease aetiology. In a survey of the counties of Great Britain conducted by John Speed in 1676, the author remarked on the unhealthy air of Cambridgeshire, "This Province is not large, nor for air greatly to be liked, having the Fenns so spread upon her North, that they infect the air far into the rest". ${ }^{2}$ Similarly, fifty years later, Daniel Defoe expressed his relief on leaving the Fens, "for 'tis a horrid air for a stranger to breathe in". ${ }^{13}$ The concept of infected air was visualized in the form of fogs and vapours. At this time they were not considered to be disease specific, but, in contrast to innocuous coastal or non-marshland fogs, they were certainly considered detrimental to the constitution. John Speed regarded the fogs of Lincolnshire to be "by reason of the Fens", but fortunately "the winds that are sent off her still working seas do disperse those vapours from all power of hurt". ${ }^{14}$

Local topographers continued into the nineteenth century to write of the "pestiferous vapours and fogs" ${ }^{15}$ but, in a significant advancement from the general notion that they were in some way malignant or injurious to health, authors remarked that the fogs were carriers of a specific disease, ague. Samuel Miller and Sydney Skertchly referred to the malarial nature of fogs, noting the year in which the greatest number occurred (1865) and those with the lowest (1872 and 1875), as if to suggest that the incidence of ague was coincident with these dates. ${ }^{16}$ The link between fogs and ague also appeared in medical literature. A report in the Lancet (1838-9) recorded the opinion of a proprietor of a factory in Norfolk, who reported that "if

\footnotetext{
${ }^{10}$ The remaining 243,300 acres of

Cambridgeshire were composed of land for arable farming and pasture, and included 8,000 acres of fen or moor common land. From Charles Vancouver, General view of the agriculture of the county of Cambridge, 1794, cited in L F Salzman, The Victoria history of the counties of England: Cambridge and the Isle of Ely, Oxford University Press, 1948, vol. 2, p. 112.

${ }^{11}$ Edwin Morris, 'Malaria, its causes, effects and treatment', Prov. med. J., 1843, 6: 447-9, p. 447.

${ }^{12} \mathrm{John}$ Speed, The theatre of the empire of Great Britain, London, 1676, p. 37.
}

\footnotetext{
${ }^{13}$ Daniel Defoe, $A$ tour through the whole island of Great Britain, Harmondsworth, Penguin Books, with an Introduction by Pat Rogers, 1971, originally published $1724-6$, p. 415 .

${ }^{14}$ Speed, op. cit., note 12 above, p. 63.

${ }^{15}$ William Watson, An historical account of the ancient town and port of Wisbech, in the Isle of Ely, in the county of Cambridge: and of the circumjacent towns and villages, the drainage of the great level of the Fens, the origin of the royal franchise of the Isle of Ely, \&c., Wisbech, $\mathrm{H}$ and $\mathrm{J}$ Leach, 1827, p. 108 .

${ }^{16}$ Miller and Skertchly, op. cit., note 3 above, p. 236.
} 


\section{Fenland Ague in the Nineteenth Century}

any of his men went beyond the bound of the premises before seven o'clock in the morning, when the fogs were prevalent, they were sure to contract ague; they might, however, pass the bounds in the after-part of the day with impunity". ${ }^{17}$ Although the connection between fogs and ague seems to be mostly unsubstantiated, ${ }^{18}$ it is perhaps not entirely unfounded. It is worth considering that a coincidental factor such as fog might have seemed plausible in the absence of any other explanation for the transmission of ague.

Concurrent with the persisting notion of malarial fogs in the late eighteenth to early nineteenth centuries, the concept of miasma or effluvia emerged in local medical and topographical literature. Many authors supposed that these substances arose from stagnant water or from decaying and decomposing animal and vegetable matter. For the Fenlanders, the primary source of miasma was the marshes in which they lived. The land was flooded in a series of stagnant pools and ditches, under which lay sodden plants and grasses. The miasmatic emanations were graphically described by Robert Hamilton, who wrote: "The stench of the exhalations issuing from the corrupted, stagnant water, and putrid, half dried mud or ooze, was most intolerably offensive ... the effluvia was almost suffocating; and it was impossible to avoid a nausea, a languor, and constant spitting whilst within their influence". ${ }^{19}$

For Miller and Skertchly, this marsh miasma was "the essential factor in producing ague". ${ }^{20}$ The idea was reinforced in national literature, for example by W C Maclean in 1895, "The terms marsh miasm and paludal fevers [his italics], long employed to distinguish the poison and the fevers to which it gives rise, mark the almost universal belief that the air of marshes alone is endowed with the power of generating them". ${ }^{21}$

However, there was much confusion, both locally and nationally, as to the exact composition of miasma. Some considered it to be of a particulate nature-a chemical, physical or biological thing. Miller and Skertchly describe air "impregnated with miasma [their italics] i.e. fine floating particles of poisonous matter exhaled from putrefying vegetable or animal substances". ${ }^{22}$ Similarly, some considered the miasma to be complex chemical molecules, which, once introduced into the bloodstream, would lead to tissue changes and the symptoms of ague. ${ }^{23}$ This reflects the popular ontological conception of disease, characteristic of the nineteenth century. ${ }^{24}$ Others

\footnotetext{
${ }^{17}$ Dr Chowne, Westminster Medical Society, Saturday, March 2, 1839, Lancet, 1838-9, i: 875-6, p. 876.

${ }^{18}$ Mortality from ague during the years noted by Miller and Skertchly was not exceptional, see Figure 4.

${ }^{19}$ Hamilton, op. cit., note 6 above, p. 37.

${ }^{20}$ Miller and Skertchly, op. cit., note 3 above, p. 415 .

${ }^{21}$ Paludal fever is one of many synonyms for ague or malaria. See Richard Quain (ed.), $A$ dictionary of medicine, 2 vols, London, Longmans, Green, 1895, vol. 2, p. 3.
}

\footnotetext{
${ }^{22}$ Miller and Skertchly, op. cit., note 3 above, p. 415 .

${ }^{23} \mathrm{M}$ Worboys, 'From miasma to germs: malaria 1850-1879', Parassitologia, 1994, 36: 61-8, p. 62.

${ }^{24}$ Christopher Hamlin writes that ontological and physiological conceptions of disease were interchangeable in the nineteenth century (see Public health and social justice in the age of Chadwick: Britain, 1800-1854, Cambridge University Press, 1998, p. 60).
} 


\section{Alice Nicholls}

described it simply as air vitiated in some way, that it "acted by affecting the tenacity of the atmosphere, or by altering the proportions of its different constituents" ${ }^{25}$ It was this explanation of miasma, and its seemingly inextricable link with ague, that led to the use of the word mal'aria, meaning "bad air". ${ }^{26}$

Whatever the nature of miasma, there appeared to be three ways in which it could enter the body. The first was by direct inhalation. According to Miller and Skertchly, those living on the ground floor of houses were more susceptible to this form of infection than those on higher floors. "The poisonous matter is somewhat heavier than air" they reasoned, and hence more highly concentrated at ground floor level. ${ }^{27}$ The second route of infection, by drinking marsh water, was linked to the first by the same authors, who concluded by experiment that "dew collected from the leaves and grass, and the top waters taken in the morning from the surface of ponds in a malarial region, are capable of producing ague in man ... Hence it appears that dew carries down the miasma from the lowest stratum of the air"' ${ }^{28}$ The authors give local evidence of the dangers of drinking marsh water, recording an instance in which "in the parish of Houghton, almost the only family which escaped ague at one time was that of a farmer who used well water, while all the other persons drank ditch water". ${ }^{29}$ Similarly, Trevor Bevis, writing of the spectrum of disease in March, Cambridgeshire, during the year 1849, implies that the ague and fevers suffered by one family were caused by drinking river water. ${ }^{30}$ The link between ague and stagnant, impure water (whether its miasmatic emanations were inhaled, or the water drunk directly) was widely recognized, with an author suggesting in the Lancet that the term malaria be exchanged for "mal'aqua". ${ }^{31}$ The third route was by ingestion of the miasma. Robert Hamilton of King's Lynn considered the cause of intermittent fevers to be "the marsh miasmata taken into the alimentary canal, by swallowing the saliva and common ingesta". ${ }^{32}$

Regardless of its composition or mode of introduction into the body, the marsh miasma was a known threat to nineteenth-century Fenlanders. The area had gained a somewhat mystical reputation for its fogs and fevers, to the extent that many were "fearful of entering the fens of Cambridgeshire, lest the Marsh Miasma should shorten their lives". ${ }^{33}$

\footnotetext{
${ }^{25}$ Dr Addison, Westminster Medical Society, Saturday, February 16, 1839, Lancet, 1838-9, i: $811-14$, p. 811.

${ }^{26}$ Dobson (op. cit., note 3 above, pp. 307-9) shows that the word malaria achieved popular usage in the English language following the publication in 1827 of John MacCulloch's book, Malaria, an essay on the production and propagation of this poison and on the nature and localities of the places by which it is produced.
}

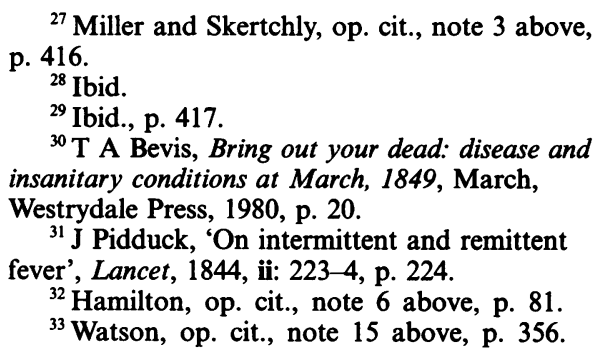




\section{Fenland Ague in the Nineteenth Century}

\section{Prevalence of Ague}

Ague was certainly prevalent in the marshes of south-east England by the sixteenth century. ${ }^{34}$ In the Fens, the demographic and epidemiological impact of the disease was increasingly significant into the seventeenth and eighteenth centuries, when, according to one source, at least half the population of the area suffered from ague. ${ }^{35}$ By the nineteenth century the prevalence was declining, although contemporary authors reported that it continued to be endemic in the Fens for much of the century. ${ }^{36}$ However, their discussion was highly subjective. Many referred to the incidence of ague but few attempted to quantify it, tending to report a change in the incidence of the disease, without supplying supporting figures. The 1850 report to the General Board of Health for the city of Ely recorded that, counter to the "diminution of ague during the twenty years preceding 1846", there had been "a great deal of ague within the last two years"; in particular there had been "much" ague and intermittent fever at Cuckold's Haven. ${ }^{37}$ Similarly, the continuing incidence of the disease in Bourne, Spalding and Long Sutton in Lincolnshire, and in Peterborough, Witchford, Whittlesey, Bluntisham, Willingham, Chatteris, Cambridge and Waterbeach in Cambridgeshire during the 1850 s and 1860 s, was contrasted with a more widespread distribution in the earlier part of the century. ${ }^{38}$

An invaluable insight into the prevalence of ague in the Fens can be gained from a paper prepared for the Privy Council in 1864 entitled Report by $\mathrm{Dr}$ George Whitley as to the quantity of ague and other malarious diseases now prevailing in the principal marsh districts of England. ${ }^{39} \mathrm{Dr}$ Whitley visited 54 districts consulting medical men (private and parochial), registrars of deaths, schoolmasters, records held in dispensaries and hospitals, and the local inhabitants. He encountered many problems in discerning an accurate, numerical account of the incidence of ague: namely, that there was not a consistent record of the reason for admittance to hospital; that many patients purchased quinine directly from the druggist and therefore never consulted a doctor, and that if a doctor was consulted, he rarely recorded the number of patients he had seen with symptoms of the disease. Nevertheless, Whitley attempted to record the incidence of ague in the previous decades, noting any periods of unusually high occurrence, and, where possible, including tables of the number of patients presenting with the disease at dispensaries and hospitals. He reported on 17 towns and cities in

\footnotetext{
${ }^{34}$ Dobson, op. cit., note 3 above, p. 343.

${ }^{35}$ John Grange, 'Cambridgeshire country cures: malaria was endemic in the Fens until the 1860 s. Did the folk cures frighten it away?', Cambridgeshire, Huntingdon and Peterborough Life, May 1985, 17 (211), p. 29.

${ }^{36}$ Nuttall, et al., op. cit., note 2 above, pp. 26-7.

${ }^{37}$ Report to the General Board of Health on a preliminary inquiry into the sewerage, drainage
}

and supply of water, and the sanitary condition of the inhabitants of the city of Ely in the county of Cambridge (William Lee), 1850, pp. 13-15. $39-40$.

${ }^{38}$ Nuttall, et al., op. cit., note 2 above, pp.

${ }^{39}$ Sixth report of the Medical Officer of the Privy Council, op. cit., note 3 above, Appendix 13. 


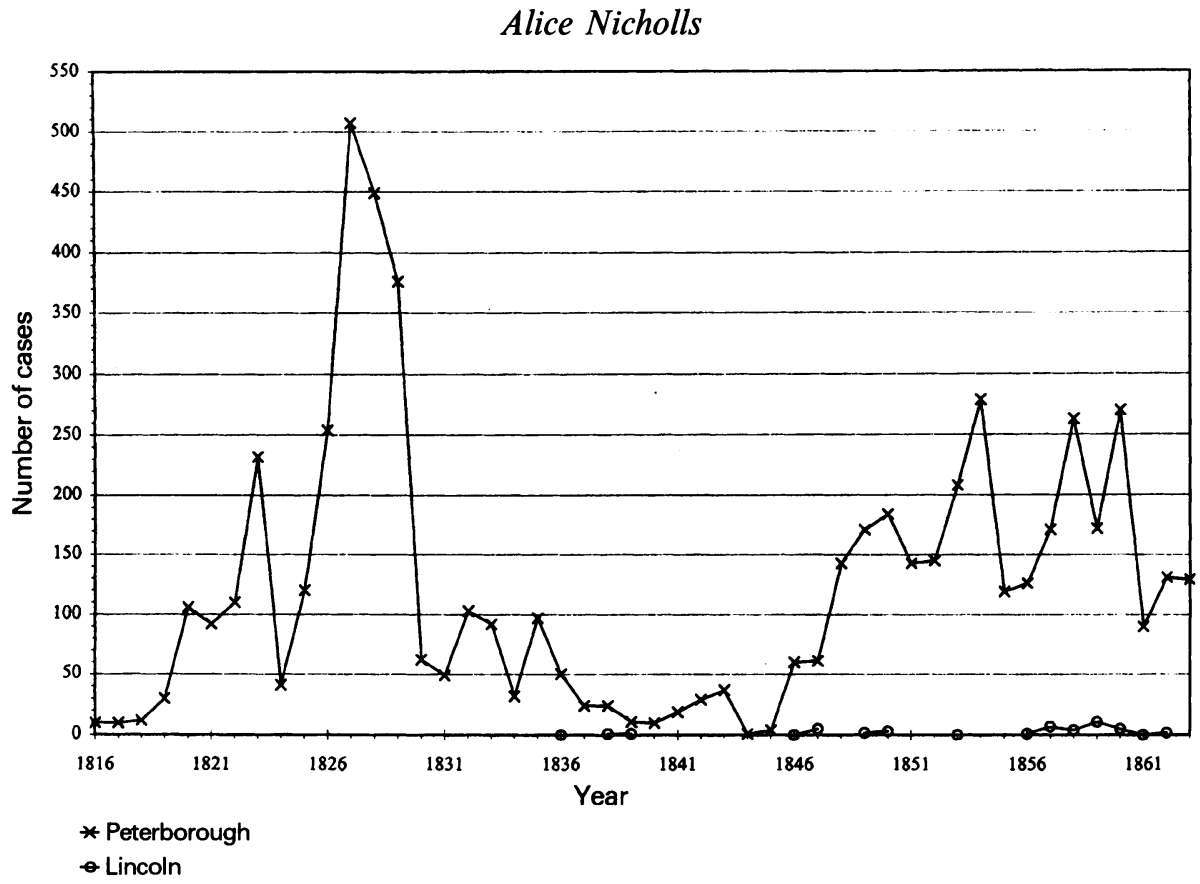

Figure 2: Outpatients with ague treated at Peterborough Infirmary and Dispensary and Lincoln Hospital, 1816-1863

Source: Sixth report of the Medical Officer of the Privy Council with appendix, 1863, London, HMSO, 1864, Appendix 13.

the counties of Cambridgeshire, Norfolk and Lincolnshire, 12 of which fell within the boundaries of the Fens. He recorded that most of the towns and cities in the Fens had suffered severely from ague twenty to thirty years previously; Peterborough and Spalding recorded an epidemic during 1826-9, and most towns witnessed ague in epidemic proportions during 1857-60.

Four locations carried statistics for the number of ague cases treated by hospitals and dispensaries-Norwich, Peterborough, Spalding and Lincoln. Figure 2 illustrates the number of outpatients treated at hospitals in a Fenland city, Peterborough, and a city on the northern limit of the Fens, Lincoln. Peterborough Infirmary and Dispensary treated patients from the surrounding fens of Lincolnshire and Cambridgeshire, whereas Lincoln Hospital received a large proportion of patients from areas outside the Fens. The graph shows that ague was a significant and integral part of the Fenland disease spectrum considering the low population densities of the area. It also depicts the trends during the period, such as the epidemics of 1826-9 and 1857-60, and the intervening "healthier" period. Surprisingly, mortality from ague in the nineteenth century did not follow these trends. 


\section{Fenland Ague in the Nineteenth Century}

\section{Mortality from Ague}

The demographic impact of the mortal marshlands of south-east England was most significant in the 200 years preceding the nineteenth century. Dobson's thorough investigation of demographic and epidemiological patterns in the marshes of Essex, Kent and Sussex in the early modern period has revealed much about the mortality of these environments. From the beginning of the seventeenth century until the end of the eighteenth, burials outnumbered baptisms in each decade (except in the 1690s) in the twenty-four marshland parishes examined. ${ }^{40}$ Estimated average annual Crude Death Rates (CDRs) for these parishes during the seventeenth century were greater than those for other parts of south-east England, ${ }^{41}$ showing the strength of association between high levels of mortality and marshland environments. During the eighteenth century, the mean CDR of marsh parishes decreased from 62 to 29 per 1000, as baptisms began to surpass burials. ${ }^{42}$ The annual mortality curves for the 200-year period are particularly revealing. Marshland parishes recorded a continually elevated annual number of burials, with frequent occurrence of pronounced peaks. Unlike in urban areas where burials gently fluctuated, occasionally interrupted by a crisis of unprecedented intensity, mortality was a familiar feature of marshland communities. ${ }^{43}$

Another indicator of the health and mortality in the Fenlands is the Infant Mortality Rate (IMR). The number of infant deaths under the age of one year per 1000 births can be used as an index to the mortality of the environment. Not surprisingly, IMRs in the Fens were consistently higher than in many other parts of Britain. Figure 3 shows the average IMR for the five counties-Lincolnshire, Norfolk, Suffolk, Cambridgeshire and Huntingdonshire, during the period 1841-99. The highest IMRs recorded were 167 per 1000 in 1846, followed by 166 in 1855 and 165 in 1861. These results are not comparable with IMRs recorded in individual Fenland towns (see Table 1). This is probably due to the fact that the values shown in Figure 3 were averaged over five counties, parts of which lie outside the boundaries of the Fens. However, the graph does illustrate the decline in IMR over the period recorded.

Fenland towns, such as those listed in Table 1, had witnessed elevated IMRs for many years. Wrigley et al. record IMRs reaching 311 per 1000 in the town of March during the period $1675-1749 .{ }^{44}$ By the 1860 s, the IMRs for the Fenland towns had fallen, but were still significantly higher than the average IMR for England and Wales (177 per 1000). That of Wisbech was comparable to some of the largest industrial towns and cities of England, such as Liverpool (277 per 1000) and Coventry (275 per 1000). ${ }^{45}$

To what extent ague contributed to the infant mortality of the Fens in the nineteenth century is difficult to ascertain. Dr Henry Julian Hunter, writing in 1864, considered the elevated IMR in marshland towns to be registered under

${ }^{40}$ Dobson, op. cit., note 3 above, p. 118.

${ }^{41}$ Ibid., p. 135.

${ }^{42}$ Ibid., p. 151 .

${ }^{43}$ Ibid., pp. 191-3.

${ }^{44}$ E A Wrigley, R S Davies, J E Oeppen, R S Schofield, English population history from family reconstitution, 1580-1837, Cambridge University Press, 1997, p. 233.

${ }^{45}$ Sixth report of the Medical Officer of the Privy Council, op. cit., note 3 above, Appendix 14, p. 454. 


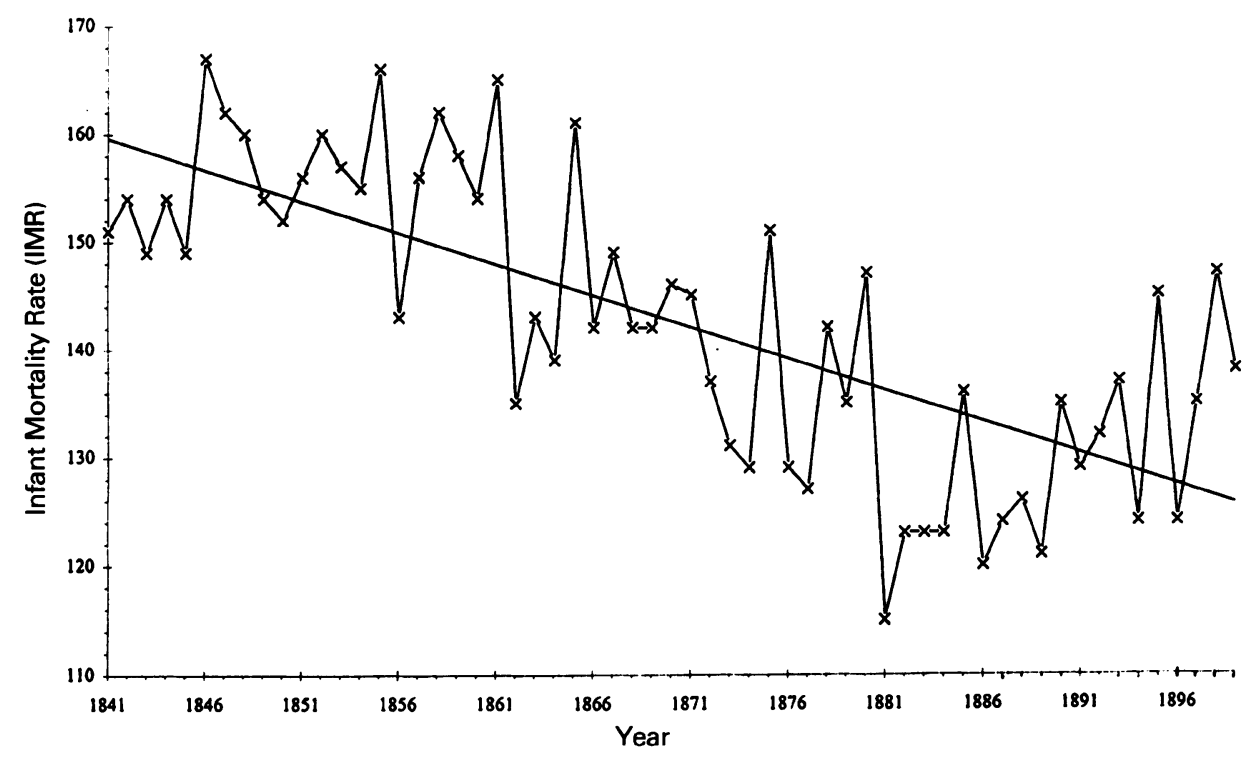

Figure 3: Infant Mortality Rates 1841-1899 (Lincolnshire, Norfolk, Suffolk, Cambridgeshire and Huntingdonshire). Infant Mortality Rates calculated as the number of infant deaths under the age of one year per 1000 births.

Source: Annual reports of the Registrar General of Births, Deaths and Marriages in England, 1841-1899.

Table 1

Infant Mortality Rates (IMRs) for towns in the

Fens, 1863

\begin{tabular}{ll}
\hline Location & IMR \\
\hline Wisbech & 260 \\
Whittlesey & 238 \\
Holbeach & 235 \\
Downham Market & 231 \\
King's Lynn & 226 \\
Ely & 220 \\
Spalding & 218 \\
\hline
\end{tabular}

Source: Sixth report of the Medical Officer of the Privy Council with appendix, 1863, London, HMSO, 1864, Appendix 14. 


\section{Fenland Ague in the Nineteenth Century}

three accounts: a large number of premature births (leading to premature death), marriages of consanguinity, and a high incidence of infant neglect. ${ }^{46}$ These circumstances arose because of the social systems peculiar to the Fens: women (even those who were pregnant) and children over the age of eight worked as labourers on the fertile, drained land, the mothers leaving babies in the care of older siblings, who dosed them with opiates in order to sedate them. ${ }^{47}$ In Hunter's report there is no mention of diseases of infancy and childhood, or of succumbing directly to ague.

Similarly, it is difficult to quantify exactly the impact of ague on adult mortality. Cause of death data is notoriously difficult to interpret for a number of reasons. Firstly, there is uncertainty in the reliability of diagnosis based on differential symptoms. "Fever" could result from a number of diseases-ague, influenza, typhoid, tuberculosis — each with a different pathogenesis and prognosis. Secondly, in an age of myriad infectious, water-borne and deficiency diseases, it is difficult to identify the terminating cause of death. To quote Dobson, "the vagueness, the imprecision and the mystery of past nosologies" make analysis of cause of death data difficult. ${ }^{48}$

The annual reports of the Registrar General of Births, Deaths and Marriages in England began in 1838, but it was not until 1848 that the number of deaths by county and by cause were fully recorded. Figure 4 illustrates the trend in the number of deaths from ague in the Fenland counties (Lincolnshire, Norfolk, Suffolk, Cambridgeshire and Huntingdonshire combined) in the remaining years of the century. Any tentative conclusion based on the number of ague deaths at county level is distorted by the fact that the eastern parts of Norfolk and Suffolk lie outside the Fens. Similarly, the local diversity occurring at smaller levels of aggregation is not considered. The figures taken from the reports are for death from ague or intermittent fever, as opposed to remittent or continued fevers with which ague was classified for the duration of the century. The graph shows the decline in mortality from ague, from a relatively high 56 deaths in 1848 , to a negligible 5 deaths in 1899. The lowest number of deaths was recorded in 1885 , when only 2 people were reported to have died from ague throughout the five counties. The epidemic of 1857-60 makes little noticeable difference to the trend in mortality. Considering the continued prevalence of the disease during the nineteenth century, ague claimed few lives.

Other contemporary authors referred to mortality from ague, although none provided such a complete set of obșervations as did the Registrar General. This may have been because mortality from the disease in specific locations was negligible and hardly warranted a mention. Yet, in the town of March during the twelve months ending Michaelmas 1849, Trevor Bevis cites 43 deaths from ague, 32 being centred around one location, Whittle End. The surrounding area, the North Witchford Union, which included the town, witnessed a total of 101 deaths from ague during

\footnotetext{
${ }^{46}$ Ibid., pp. 454-61.

${ }^{47}$ The Cambridge Chronicle frequently reported inquests into the death of infants due to overdosing with opiates. See 21 September 1850 ,
}

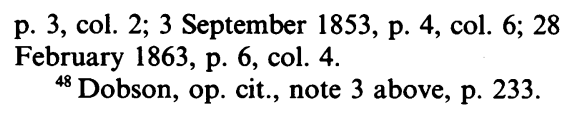




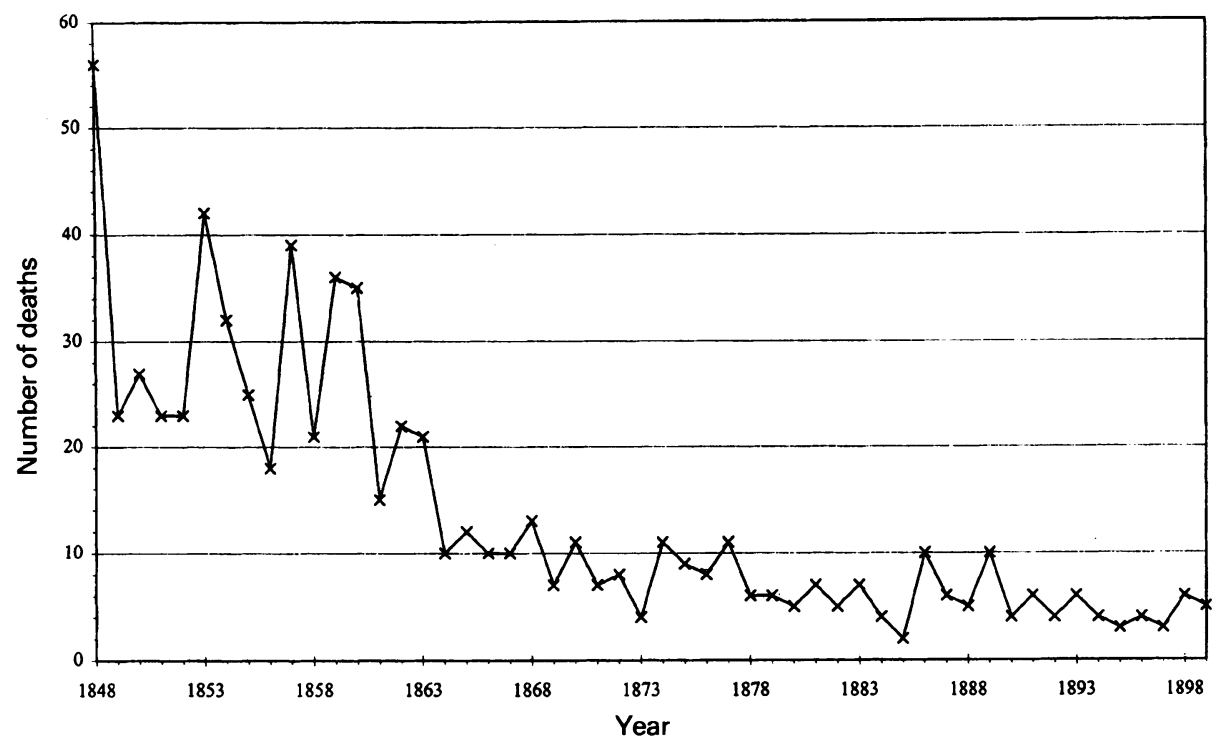

Figure 4: Number of deaths from ague 1848-99 (Lincolnshire, Norfolk, Suffolk, Cambridgeshire and Huntingdonshire).

Source: Annual reports of the Registrar General of Births, Deaths and Marriages in England, 1848-1899.

that year. ${ }^{49}$ A localized outbreak of this intensity does not seem to be recorded elsewhere. In the annual reports on the sanitary condition of the Cambridge Improvement Act District, in the years 1875-99, only a single death was recorded in each of the years 1889,1890 and 1897 . There were no fatalities from ague in the intervening years. ${ }^{50}$ These figures reflect the trend towards declining mortality from ague as illustrated in Figure 4.

Mortality in Huntingdon and Wisbech was also elevated during certain periods of the nineteenth century (see Table 2). Although an eight-year span is hardly indicative of the century as a whole, it is possible to make some important observations. In Huntingdon, ague was a consistent cause of death, whereas fatalities from ague in Wisbech were sporadic. Yet, as a percentage of all fatalities, ague did not rise above 3 per cent, insubstantial in comparison to the likely number of fatalities from typhus or influenza. The figures do not continue into the 1860 s, so it is impossible to discern whether either town was subject to the epidemic raging throughout the Fens at this time. There is a small increase in the proportion of fatalities in both towns during 1857 , but the following year shows a lower incidence

\footnotetext{
${ }^{49}$ Bevis, op. cit., note 30 above, p. 10.

${ }^{50}$ Report on the sanitary condition of the Cambridge Improvement Act District (Bushell Anningson, MOH), 1875-99.
} 
Fenland Ague in the Nineteenth Century

Table 2

Proportion of deaths from ague per 1000 deaths from all causes in Huntingdon and Wisbech, $1850-1858$

\begin{tabular}{lcl}
\hline Year & Huntingdon & Wisbech \\
\hline 1850 & not recorded & 4.5 \\
1851 & 7.2 & 0 \\
1852 & 11.6 & 5.7 \\
1853 & 34.09 & 3.4 \\
1854 & 7.5 & 1.05 \\
1855 & 7.7 & 0 \\
1856 & 5.4 & 2.94 \\
1857 & 12.1 & 9.1 \\
1858 & 2.3 & 6.4 \\
\hline
\end{tabular}

Source: Thomas B Peacock, 'On the recently prevalent malarious affections', Med. Times Gaz., 1859, 19: p. 399.

Table 3

Incidence and outcome of ague cases referred to Peterborough Infirmary, 1845-59

\begin{tabular}{lc}
\hline Outcome of treatment & Number of cases \\
\hline Cured & 2173 \\
Much relieved & 4 \\
Somewhat relieved & 2 \\
Not relieved & 0 \\
Non-attendance & 81 \\
Dead & 1 \\
Parish paupers & 2 \\
Too ill to attend & 4 \\
& 2267 \\
\hline
\end{tabular}

Source: Sixth report of the Medical Officer of the Privy Council with appendix, 1863, London, HMSO, 1864, Appendix 13.

of ague deaths. Finally, in the year of the greatest number of fatalities from ague in Huntingdon, Wisbech did not witness a corresponding increase. This may be evidence for the conclusion that ague was largely endemic in the Fens, creating a unique pattern of morbidity and mortality in each location.

Despite some sporadic fatalities from ague, most people survived the infection. The incidence and outcome of ague cases referred to Peterborough Infirmary (1845-59) are representative of this trend-there was only one fatality in 2267 cases (see Table 3). 


\section{Alice Nicholls}

\section{Chronic State of Ill-Health}

Ague was only occasionally fatal, but "though of less formidable intensity here than in those hotter climates, marsh-malaria was a great morbidific influence in England". ${ }^{51}$ Some Fenlanders died soon after contracting the disease, probably due to predisposing factors such as limited immunity. More often, the debilitating symptoms of ague generated a chronic state of ill-health, in which symptoms of the disease, such as anaemia or physical frailty, often proved fatal. As Edwin Morris wrote in 1843, the "marsh miasma exerts a most deadly influence upon the system, it lowers the pulse, it prostrates the strength, and affects the mind, and renders life miserable indeed". ${ }^{52}$ The paroxysms were exhausting, and often patients did not fully recover, enduring mild paroxysms for many months after the initial attack. The persistence of the disease prevented an effective recovery. Morris commented, "It is not at all an uncommon occurrence for malaria to lurk in the system for weeks, nay, even months, harassing the individual, and producing great debility and lowness of spirits"..$^{3}$

The infirmity and malaise caused by ague contributed to a lowered resistance to other diseases. The Fenlanders were particularly susceptible to typhoid and water-borne enteric diseases which shared a similar environmental, seasonal and climatic distribution with ague. In 1864, George Whitley remarked on the connection between ague and typhoid, "the local conditions which produce the former are favourable to the development of the latter". ${ }^{54}$ Fatality rates from typhoid were likely to have been elevated by the chronic, debilitated state of health induced by ague. This interaction was noted by Morris: "I am fully persuaded that one-half of the diseases we are called upon to treat in the fens of Lincolnshire are caused by malaria". ${ }^{55}$

Similarly, mortality from ague was probably increased by secondary infections: the virulence of ague augmented by the reduced condition of the patient. This comorbidity is highlighted in Table 4, which shows the distribution of three diseases, typhus, ague and diarrhoea, in the town of Chatteris in 1852. Notably, the areas of the town in which the prevalence of one disease was high invariably also displayed an elevated number of cases of the other diseases. Infections were concentrated in distinct locations, such as Hive End, which witnessed a particularly high incidence of both typhus and ague. This may have been a large area, therefore accumulating more cases, or it could have been a location with an abundance of stagnant pools, open sewers and poor housing-environmental and sanitary conditions conducive to infection with ague and typhus.

\footnotetext{
${ }^{51}$ Sixth report of the Medical Officer of the Privy Council, op. cit., note 3 above, p. 32.

${ }_{52}$ Edwin Morris, 'Further observations upon malaria', Prov. med. J., 1843, 6: 521-3, p. 522.
}

${ }^{53}$ Morris, op. cit., note 11 above, p. 447.

${ }^{54}$ Sixth report of the Medical Officer of the Privy Council, op. cit., note 3 above, p. 452.

${ }^{55}$ Morris, op. cit., note 52 above, p. 522. 
Table 4

The distribution of typhus, ague and diarrhoea in the town of Chatteris in 1852 (two districts)

\begin{tabular}{lccc}
\hline AREA & TYPHUS & AGUE & DIARRHOEA \\
\hline $\begin{array}{l}\text { North of Slade Lode Bridge, the Gault and } \\
\text { Chapman's Yard }\end{array}$ & 9 & 12 & 6 \\
South of Slade Lode Bridge, Skeel's Yard and & 9 & 8 & 5 \\
$\begin{array}{l}\text { Lane, Cole's Yard and Old Work-house Lane } \\
\text { Slade End north of the Bank, incl. Palmer's }\end{array}$ & & & \\
Yard, Clark's Yard, Porter's Yard and Moxon's & 8 & 1 & 3 \\
Yard & 10 & 1 & 1 \\
Back Lane incl. Negus's and Cropley's Yards & 1 & 1 & 1 \\
High St., near Brooks Corner, \&c. & 9 & 3 & 1 \\
New Road & 5 & 1 & 0 \\
Horseway & 51 & 27 & 17 \\
Total & TYPHUS & AGUE & DIARRHOEA \\
\hline AREA & & & \\
\hline Hive End, incl. the Dark Lane, Drake's Yard, & 48 & 26 & 1 \\
Garrett's Yard and Gascoyne's Yard & 3 & 1 & 2 \\
Mill End & 20 & 0 & 1 \\
Curtis's Rows & 2 & 0 & 0 \\
Station St. & 3 & 0 & 0 \\
Stuck's Yard and the Lane & 0 & 0 & 1 \\
Smart's Lane & 76 & 27 & 5 \\
Total & & & \\
\hline
\end{tabular}

Source: Thomas Tusting, The sickness and mortality of Chatteris, March, Ward, 1853.

\section{Impact of Ague on Everyday Life}

Ague gave rise to peculiar social, demographic and economic structures in the Fenlands, which in turn reinforced the ill-health of the inhabitants. The virulence of ague often deterred people from entering the area, whether traders or potential settlers. Those seeking to trade in the Fenland counties, such as opium dealers, rarely strayed beyond the main arteries into the market towns, leaving the distribution of goods into the depths of the marshes to the local tradesmen. The affluent moved away, as advocated by doctors, "undoubtedly change of residence to a more healthy district is the best course to adopt; but all have not the means of taking advantage of this" ${ }^{56}$ Those who remained in the Fens were the poor, agricultural labourers who invested their future in the fertile land. Their income was dependent upon a good harvest, and women and children were drafted into the fields to carry out manual labour for meagre wages. If the harvest was exiguous, many families could

${ }^{56}$ Morris, op. cit., note 11 above, p. 448. 


\section{Alice Nicholls}

be plunged into poverty, their health suffering as a consequence of their poor diet. James Wentworth-Day refers to a family, the Badcocks, living in Burwell Fen, who "thought nothing of having a mess o' water-rats for supper". ${ }^{57}$

In addition to the low population density and non-residence of the rich and educated, there was a significant immigration of non-immunes. Every couple of years men from the Fens would visit the surrounding upland counties, such as Nottinghamshire, in search of new brides, their previous wives having succumbed to the ague. This event tended to occur every two to three years because the new wives, being strangers to the Fens, would quickly become infected, and not having encountered this disease in their upland parishes, they had little immunity to it and consequently died. This oral tradition is corroborated by evidence in Defoe's book that this practice also took place in the marshes of Essex. ${ }^{58}$

Although the issue of biological immunity in those constantly exposed to the disease was debated by authors of medical textbooks in the second half of the century, ${ }^{59}$ the Fenlanders certainly learned to cope with the illness, devising and employing effective remedies - prophylactic, palliative and curative. Even during the eighteenth century, when mortality from ague was still high, Defoe noted that they "live unconcerned, and as healthy as other folks, except now and then an ague, which they make light of" ${ }^{\prime 60}$ When mortality from ague decreased in the following century, the disease was regarded as a minor affliction, inherent in the environment in which they lived, and to which they had become accustomed.

\section{Conclusion}

The decline of ague in the Fens was gradual, as reflected by mortality from the disease throughout the century. It was not eradicated simultaneously across the Fens, and it is possible that in some parts the disease persisted in a very mild form into the beginning of the twentieth century. The contemporary explanation for its diminishing incidence was the drainage of the marshlands, and the disappearance of the noxious vapours and fogs, or marsh miasma. Whitley concluded that the decrease in frequency and severity of ague was "attributed in very nearly every case, mainly to one cause, improved land

\footnotetext{
${ }^{57} \mathrm{~J}$ Wentworth-Day, $A$ history of the Fens: being some account of their swamps, meres, men, sports, duck decoys, drainage, riots, floods, legends, fish and fowl, London, George G Harrap, 1954, p. 144.

${ }^{58}$ Defoe, op. cit., note 13 above, p. 55.

${ }^{59}$ John Syer Bristowe wrote in 1880 that, "It seems to be well ascertained that the denizens of malarious districts become, in a greater or less degree, acclimatised, and hence less readily contract ague than persons newly arrived" $(A$ treatise on the theory and practice of medicine, 3rd
}

ed., London, Smith, Elder, 1880, p. 260). In contrast, William Aitken maintained that continual residence in an area where ague prevails increases susceptibility to the disease (The science and practice of medicine, 3rd ed., 2 vols, London, Charles Griffin, 1864, p. 507), as did Thomas Hawkes Tanner, who listed "the circumstance of once having suffered from it" as a predisposing factor to ague (The practice of medicine, 6th ed., 2 vols, London, Henry Renshaw, 1869 , vol. 1 , p. 259).

${ }^{60}$ Defoe, op. cit., note 13 above, p. 101. 


\section{Fenland Ague in the Nineteenth Century}

drainage". ${ }^{61}$ Similarly, Morris commented, "fever, particularly that of the intermittent form, has been less frequent since the more perfect and effective drainage of the marshy districts of Lincolnshire". ${ }^{62}$

In modern terms, the drainage of the land, although not as comprehensive as nineteenth-century observers would lead us to believe, would have reduced the number and density of Anopheles breeding grounds. Much of the Fens in the late nineteenth century was still marshland, drained by deep ditches with slow moving water, but reclamation and agricultural utilization of the land had decreased the number of stagnant pools. A reduction in the number of breeding grounds and an increase in the distance between them and the blood meal would have led to a decrease in biting frequency, and thus to a reduction in the transmission of malaria. At some point, this was sufficient to depress its incidence below a critical level, until the disease was completely eliminated.

Other factors may also have contributed to the abatement of the disease. Dobson, referring to the decline of malaria in the south-eastern counties, postulates the influence of:

... separation of humans, animals and mosquitoes, the overwintering of cattle and the specific use of bark ... changing demographic structures and decreasing rates of inmigration ... a decreasing influx of "new" infections ... an increased resistance to malaria and to other intercurrent infections, and the possible emergence of milder or fewer strains of malaria. ${ }^{63}$

These factors may have acted individually or in conjunction with each other, simultaneously or at different periods in time, but, without further research, it is impossible to assess their influence on the decline of ague in the Fens.

In the light of the comprehensive research regarding ague in the marshes of Essex, Kent and Sussex, this paper discusses only a fraction of the nineteenth-century history of ague in the Fens. Patterns of prevalence, mortality and morbidity could be further investigated at smaller units of aggregation, such as at parish level. Further examination of the distribution of Anopheles mosquitoes is needed, and of the reasons for the decline of the disease.

The core of this paper lies in the Fenland perception of the disease. Ague was a familiar entity to the inhabitants of the marshland, as the synonyms for the disease suggest. They lived in houses raised above the watery Fens, reasoning that infection from the marsh miasma was less likely on higher floors. Economic and social structures were influenced by the disease-opium traders refused to enter the depths of the Fens, leaving the distribution of goods to local tradesmen, the wealthy moved out of the area for fear that the disease would shorten their lives, and local men would periodically visit upland counties to "replace" their wives. Mortality was occasional. Of greater consequence to the Fenlanders was the fact that ague caused a chronic state of ill-health. However, over the course of the century, as the incidence

${ }^{61}$ Sixth report of the Medical Officer of the Privy Council, op. cit., note 3 above, Appendix 13, p. 450.

\footnotetext{
${ }^{62}$ Morris, op. cit., note 11 above, p. 447.

${ }^{63}$ Dobson, op. cit., note 3 above, p. 523.
} 
of the disease gradually declined, it is likely that the clinical manifestations of the disease became milder.

Ague was primarily a patient-treated illness in the Fens, with self-medication by opium and folk cures, rather than by medically approved quinine. ${ }^{64}$ Doctors rarely wrote about ague since so few patients suffering from it ever attended their surgeries. Beyond the bounds of the marshes, ague was of even less concern to doctors, politicians or the general public, and, by the time the mode of transmission of ague was discovered in 1897, the disease was not even of concern to the Fenlanders themselves.

${ }^{64}$ See Grange, op. cit., note 35 above; Enid Porter, Cambridgeshire customs and folklore, London Routledge and Kegan Paul, 1969, pp. 71-2; Susan Patterson, 'Folk cures', in Jane
Arthur (ed.), Medicine in Wisbech and the Fens 1700-1920, Wisbech, Seagull Enterprises, 1985, pp. 21-34, on pp. 31-2. 